\title{
SSynthesis
}

International Scientific Conference of IT and Business-Related Research

\section{PRIMENA TEHNIKE UPRAVLJANJA PRINOSIMA U HOTELIJERSTVU U SRBIJI}

\section{THE USAGE OF YIELD MANAGEMENT IN HOSPITALITY INDUSTRY IN SERBIA}

\author{
Nikica Radović, Tijana Radojević \\ Fakultet za turistički i hotelijerski menadžment, Univerzitet Singidunum, Danijelova 32, Beograd, Srbija
}

\begin{abstract}
Apstrakt:
Uspešno poslovanje preduzeća i ostvarivanje poslovnih rezultata zavise od dobro osmišljenog donošenja i realizacije poslovnih odluka. Hotelijerstvo karakteriše niz specifičnosti u poslovanju, a koje su uslovljene pravilnim poslovnim odlukama od kojih zavisi pozicioniranje preduzeća na tržištu, a posredno i ostvarivanje dobrih poslovnih rezultata. Jedan od ključnih elemenata poslovanja hotelskih preduzeća je pravilno određivanje prodajnih cena u cilju konkurentnosti na tržištu, kao i poslovne isplativnosti.

U ovom radu akcenat je na uticaju tehnika upravljanja prinosima na formiranje cena na hotelskom tržištu. Cilj rada je da se približe saznanja o primeni ove metode, kako sa teoretskog aspekta, tako i prezentovanjem rezultata o primeni u hotelijerstvu Srbije.
\end{abstract}

\section{Ključne reči:}

poslovno odlučivanje, cene, hotelijerstvo, upravljanje prinosima

\section{UVOD}

Uspešno poslovanje preduzeća zasniva se na dobro organizovanom upravljanju poslovnim procesima i donošenju odgovarajućih poslovnih odluka, koje za cilj imaju dobre rezultate poslovanja. Poslovno odlučivanje predstavlja izbor između alternativnih opcija koje u daljim poslovnim aktivnostima daju određene rezultate, uz određeni rizik i neizvesnost.

Proces donošenja odluka obuhvata više faza (Milićević, 2000):

1. Identifikovanje i analiza problema.

2. Procena alternativnih smerova aktivnosti.

3. Definisanje alternativnih smerova aktivnosti.

4. Donošenje odluke.

5. Primena odluke.

6. Nadgledanje (kontrola) odluke.

Primenom navedenih faza omogućeno je sigurnije donošenje dobrih poslovnih odluka kako bi se izbegle pogrešne koje bi negativno uticale na poslovanje preduzeća.

Hotelijerstvo predstavlja složen i specifičan sistem poslovanja u okviru kog je veoma važno pravilno poslovno odlučivanje. Specifičnosti hotelskog poslovanja karakterišu:

- Uslužna delatnost koja je uslovljena zadovoljstvom korisnika uz nezaobilaznu platežnu sposobnost.

- Sezonalnost kao vremenska dimenzija poslovanja izražena kod velikog broja smeštajnih kapaciteta.

\section{Abstract:}

Business success and achievement of business results depend on a well thought out decision-making and implementation of business decisions. The hotel industry is characterized by several specific aspects, which are conditioned by the proper business decisions of which depends on the positioning of the company in the market and, indirectly, the achievement of good business results. One of the key elements of hotel business is to correctly determine the sales price in order to market competitiveness, as well as business cost effectiveness. In this paper, the focus is on the impact of yield management pricing on the hotel market. The aim of this paper is to present the findings of the application of this method, both from a theoretical point of view as well as the results of the application in the hotel industry in Serbia.

\section{Key words:}

decision making, price, hotel industry, yield management

- Ograničenost ponude u zavisnosti od veličine (broja) smeštajnih kapaciteta koje preduzeće ima na raspolaganju.

- Visoki fiksni troškovi.

Uslovljenost navedenim specifičnostima hotelskog poslovanja ukazuje na važnost poslovnog odlučivanja u više poslovnih područja npr. u delu računovodstva troškova, budžetiranja, investiranja, politike prodajnih cena i slično.

Može se reći da je za uspešno pozicioniranje na tržištu, kao i ostvarivanje zadovoljavajućeg poslovnog rezultata veoma važno pravilno određivanje cena sa kojima hotelsko preduzeće istupa na otvoreno turističko tržište. Ovakav stav zasniva se na dobro analiziranim elementima koji utiču na formiranje cene, a u koje se ubrajaju troškovi poslovanja, platežna sposobnost korisnika uz definisanje ciljne grupe, kao i praćenje konkurencije.

Pojedini autori u svojim radovima (Nikolić, 2007; Čerović, 2009; Popesku, 2013) prezentuju modele određivanja cena koji se primenjuju u hotelskom poslovanju:

- Metod na osnovu posebnosti - Premium Pricing,

- Metod "Skidanje kajmaka" - Skimming Pricing,

- Metod diferenciranja cena - Diferential Pricing,

- Metod penetracije tržišta - Market Penetration Price,

- Metod formiranja cena u cilju preživljavanja - Survival Pricing,

- Metod "Ubiranje plodova" - Harvesting Pricing, 
- Sprečavanje ulaska konkurenata - Preventing marketing entry,

- Upravljanje prinosima i prihodima - Yield \& Revenue Management.

\section{UTICAJ TEHNIKE UPRAVLJANJA PRINOSIMA NA POLITIKU CENA U HOTELSKOM POSLOVANJU SRBIJE}

Zahvaljujući veštinama upravljanja, kao i primeni savremenih informacionih sistema preduzeća su danas u mogućnosti da ostvare svoj cilj, a to je dobar poslovni rezultat. Jedna od menadžerskih tehnika koja se primenjuje za unapređenje poslovanja uz ostvarivanje boljeg poslovnog rezultata je tehnika upravljanja prinosima.

Pojava tehnike upravljanja prinosima vezuje se za kraj XX veka i poslovanje avio-kompanija. Naime, cilj avio-kompanija je bio (i ostao) da se proda maksimalan broj sedišta u avionu na jednom letu, imajući u vidu nemogućnost skladištenja, kao specifičnost poslovanja, a samim tim i stvaranje većih troškova ukoliko se ne prodaju raspoloživi kapaciteti. Nakon toga, veliki broj uslužnih preduzeća preuzeo je ovu metodu u svom poslovanju, sa ciljem poboljšanja poslovanja uz sprečavanje gubitka prihoda zbog propuštenih prilika za prodaju svojih kapaciteta.

Tehnike upavljanja prinosima se u hotelskom poslovanju realizuju primenom određenih postupaka u procesima planiranja poslovanja, kao i donošenja određenih poslovnih odluka uz optimalnu profitabilnost poslovanja. Naime, upravljanje prinosima u hotelijerstvu predstavlja tehniku praćenja poslovanja preduzeća u okviru kog se stalnim monitoringom zauzetosti smeštajnih kapaciteta prati ostvarenje prihoda i prilagođava tržištu, sa ciljem potpunog iskorišćenja kapaciteta uz ostvarenje optimalnih prihoda. Svaka prazna soba predstavlja trošak, imajući u vidu nemogućnost skladištenja, kao mogućnost i priliku za neku buduću prodaju.

Tehnike upravljanja prinosima primenjuju sledeće elemente: rezervacije, praćenje zauzetosti soba i optimalne cene. Ovi elementi se lako optimizuju zahvaljujući primeni savremenih informacionih sistema tj. određenih poslovnih aplikacija koje hoteli danas koriste u svom poslovanju, a pomoću kojih je omogućeno lakše praćenje rezervacija kapaciteta, kao i formiranje i prilagođavanje prodajnih cena. Primenom aplikacije zaposleni i menadžment su uvek u mogućnosti da sagledaju raspoložive kapacitete hotela, a potencijalni gosti da on-line rezervišu smeštaj u željenim sobama, u odgovarajućem terminu (Radojević \& Radović, 2012).

U zavisnosti od raspoloživih kapaciteta i tražnje na tržištu moguća je politika diversifikacije prodajnih cena, ali ne sa ciljem snižavanja cena kako bi se povećao broj gostiju, nego kao metoda praćenja zauzetosti kapaciteta koji mogu biti prodati po prihvatljivim cenama na tržištu. Cene se prilagođavaju tržišnim mogućnostima, ciljnim grupama, sa idejom dostupnosti krajnjem korisniku, uz pokriće kalkulisanih troškova poslovanja.

Krajem 2014. godine sprovedena je anketa o poslovnom odlučivanju u hotelijerstvu Srbije, kojom je bilo obuhvaćeno i istraživanje o upravljanju prinosima ${ }^{1}$. Anketa je sprovedena kod pedeset hotela iz Srbije koji pripadaju kategorijama tri, četiri i pet zvezdica, a odgovori su pristigli od trideset osam hotela. Prema kategorizaciji hotela učešće $u$ anketi uzelo je pet hotela sa pet zvezdica, dvadeset hotela sa četiri zvezdice i trinaest hotela sa tri zvezdice (grafikon 1).

1 Istraživanje je sprovedeno u formi anonimnog anketnog upitnika, poslatog elektronskim putem od strane autora ovog rada.

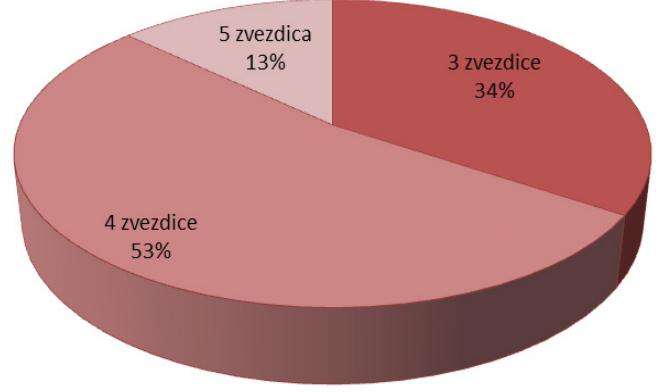

Grafikon 1. Kategorija hotela koji su učestvovali u anketi

Prema rezultatima ankete dvadeset šest hotela primanjuje tehnike upravljanja prinosima u svom poslovanju, a dvanaest hotela ne primenjuje ovu metodu (grafikon 2). Kada se to sagleda, prema kategorizaciji hotela koji su učestvovali u anketi, može se uočiti da svih pet hotela sa pet zvezdica primenjuje tehnike upravjanja prinosima. S tim u vezi, upravo strategija i politika poslovanja ovih hotela, kao i njihovi pozitivni rezultati ukazuju na prednosti primene ove tehnike. Kod hotela sa četiri zvezdice polovina učesnika koji su odgovorili, tj. deset hotela, primenjuje tehnike upravljanja prinosima, dok kod hotela sa tri zvezdice jedanaest hotela primenjuje, a dva hotela ne primenjuju ovu metodu u svom poslovanju.

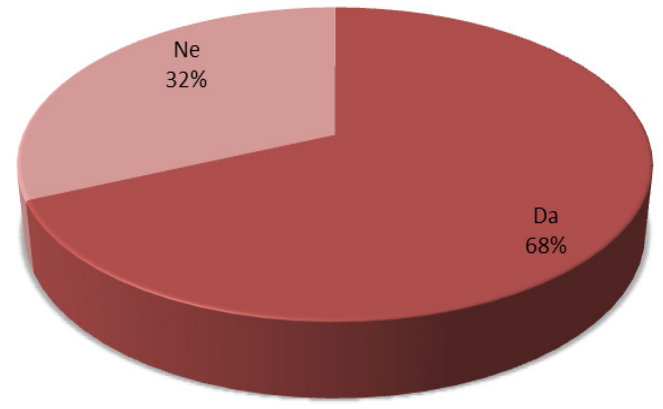

Grafikon 2. Primena tehnike upravljanja prinosima u poslovnom odlučivanju

U poslovanju hotelskih preduzeća sprovođenje poslovnih odluka razlikuje se prema nivoima menadžmenta - niži (operativni), srednji ili visoki nivo menadžmenta. Prema nivoima menadžmenta razlikuju se prirode odluka, kao i metode sprovođenja. Na osnovu rezultata dobijenih iz sprovedene ankete i odgovora na pitanje da li primenjujete tehnike upravljanja prinosima u svom poslovanju, utvrđeno je da je prema menadžment strukturi u svom poslovanju upravljanje prinosima zastupljeno kod $61 \%$ (tj. kod šesnaest) ispitanika koji pripadaju visokom menadžmentu, dok u $39 \%$ slučajeva (tj. deset ispitanika) pripada srednjem menadžmentu.

Imajući u vidu da je cilj hotelijera maksimalna popunjenost kapaciteta tj. minimum praznih soba kreiraju se različiti paketi ponude smeštajnih kapaciteta, po diferenciranim cenama npr. vikend cene, sezonske cene, porodični paket aranžmani, cene za lojalne korisnike i slično. Takođe, prilikom formiranja cena menadžeri hotelskih preduzeća se rukovode različitim pristupima, pa tako cene prezentuju po smeštajnoj jedinici za noćenje (aranžman), po osobi za noćenje (aranžman), cene u zavisnosti od vrste sobe tj. $1 / 1$ ili $1 / 2$, itd. Na osnovu rezultata ankete, a prema grafikonu 3 hotelska preduzeća u Srbiji u svom poslovanju primenjuju različite pristupe u politici cena kojom se prezentuju na turističkom tržištu. 


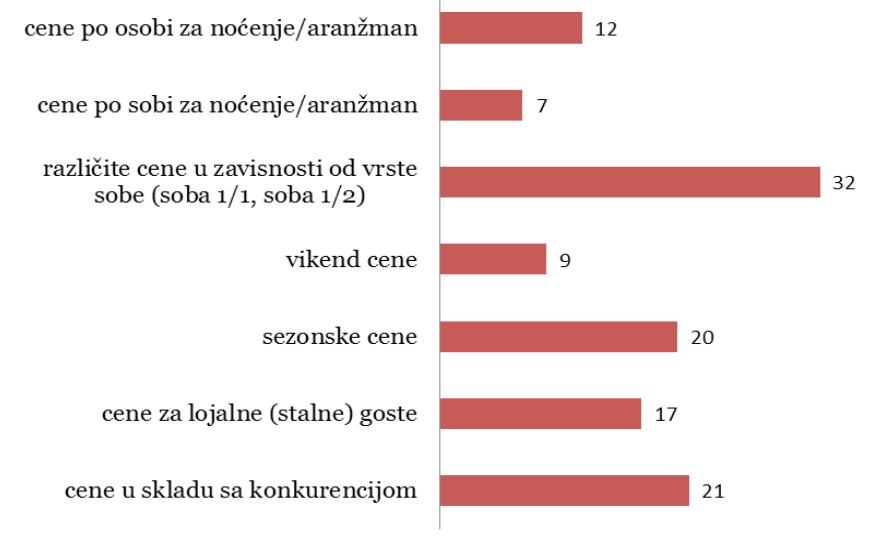

Grafikon 3. Pristupi formiranju cena hotelskih preduzeća

\section{REZIME}

Primena tehnike upravljanja prinosima doprinosi operativnoj efikasnosti u poslovanju preduzeća, i smanjenju troškova što implicira bolju produktivnost i profitabilnost preduzeća. U poslovanju hotelskih preduzeća primena tehnike upravljanja prinosima utiče na poboljšanje iskorišćenosti kapaciteta, a time i na povećanje učinka u poslovanju.

Zahvaljujući primeni informacionih hotelskih aplikacija olakšano je poslovanje hotela i omogućeno objedinjeno sagledavanje raspoloživosti smeštajnih kapaciteta, ostvarenih prihoda i rashoda u tekućem poslovanju, a na osnovu toga su formirane odgovarajuće prodajne cene u cilju konkurentnosti na tržištu i uspešne realizacije poslovnih planova.

$\mathrm{Na}$ osnovu rezultata sprovedene ankete o stepenu primene tehnike upravljanja prinosima u hotelijerstvu Srbije može se zaključiti da bi trebalo poraditi na edukaciji menadžera i zaposlenih o prednostima primene ove metode i na taj način uticati na povećanje stepena primene, što bi dovelo do poboljšanja rezultata poslovanja preduzeća u ovom sektoru, a posredno i do većeg uspeha u turizmu Srbije.

\section{LITERATURA}

Čerović, S. (2009). Strategijski menadžment u turizmu. Beograd: Univerzitet Singidunum.

Guilding, C. (2009). Accounting Essentials for Hospitality Managers. London: Elsevier.

Milićević, V. (2000). Računovodstvo troškova i poslovno odlučivanje. Beograd: Ekonomski fakultet.

Nikolić, D. (2007). Upravljanje finansijskim poslovanjem i politika cena u hotelijerstvu i turizmu. Beograd: Univerzitet Singidunum.

Popesku, J. (2013). Marketing u turizmu i hotelijerstvu. Beograd: Univerzitet Singidunum.

Radojević T., \& Radović N. (2012). Savremeno upravljanje kompanijama u hotelijerstvu primenom informacionih sistema, $17^{\text {th }}$ International Scientific Conference SM2012, 20.04.2012. Subotica: Ekonomski fakultet. 